\title{
Potential for Controlled Traffic Farming (CTF) in Grass Silage production: agronomics, system design and economics
}

by Hargreaves, P.R., Peets, S., Chamen, W.C.T., White, D.R., Misiewicz,P.A., and Godwin, R.J.

Copyright, Publisher and Additional Information: This is the author accepted manuscript. The final published version (version of record) is available online via Cambridge University Press Please refer to any applicable terms of use of the publisher.

DOI: $\underline{\text { http://dx.doi.org/10.1017/S2040470017000747 }}$

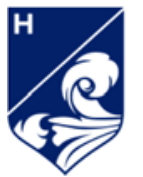

Harper Adams University 


\section{Potential for Controlled Traffic Farming (CTF) in Grass Silage Production: Agronomics, system design and economics}

Hargreaves P.R. (1), Peets S. (2), Chamen W.T.C. (3), White D.R. (2), Misiewicz P.A. (2) and Godwin R.J. (2)

(1) SRUC Dairy Research and Innovation Centre, Dumfries, UK

(Paul.Hargreaves@sruc.ac.uk),

(2) Harper Adams University, Newport, Shropshire, UK,

(3) CTF Europe Ltd, Maulden, Bedfordshire, UK.

Grassland silage management is generally ad hoc resulting in soil compaction damage.

Literature suggests grass yield reductions of 5 to $74 \%$ through compaction (UK mean 13\%), while a 2015 study, reported here, comparing grass dry matter (DM) yield between controlled traffic farming (CTF) and normal management (N), found a 13.5\% $\left(0.80 \mathrm{t} \mathrm{ha}^{-1}\right)$ increase for CTF. Commercially available grass forage equipment with widths of 3 to $12 \mathrm{~m}$ set up for CTF reduced trafficked areas from $80 \%-90 \%$ for $\mathrm{N}$ to $40 \%-13 \%$. Economic analysis based on $13 \%$ increase in DM for 2 and 3 cut systems, gave an increased grass value between $£ 38$ ha $^{-1}$ and $£ 98 \mathrm{ha}^{-1}$. CTF for multi-cut grass silage effectively increases yields by reducing compaction and sward damage.

Key words: grassland, controlled traffic, economic, silage

\section{Introduction}

Grassland silage management is generally conducted in an ad hoc manner, with no conscious attempt to re-use wheel ways as with arable fields. Traffic can cause soil compaction with increased bulk density, increased shear strength, reduced porosity (Douglas et al., 1992) and reduced air and water permeability (Davies et al., 1993; Chyba et al., 2014). Generally, moist soil is more susceptible to compaction (Alakukku, 1999) hence, in years with normal weather patterns, soil/crop damage will occur as a result of operations during the spring or autumn months. The first wheeling causes most of the compaction (Davies et al., 1993) with subsequent incremental effects as numbers of passes increases (Raghavan et al., 1977). The total number of machine passes on a field can be 11 or more with normal $(\mathrm{N})$ traffic systems; potentially a large area of the field can suffer from soil compaction damage. The extent of field traffic for a forage harvester and round baler in a study was $63.8 \%$ and $63.4 \%$ of the field area, respectively (Kroulik et al., 2014).

Soil compaction effects on grass yields have been quantified by several studies: (i) grass yield decrease due to soil compaction in the range 5-74\% (Are et al., 2015; Douglas \& Crawford, 1991 \& 1992; Frost, 1988; Rasmussen \& Møller, 1981; Reintam et al., 2013), with long-term yield decrease for UK conditions in the range of 5-20\% with a mean of $13 \%$ (Douglas and Crawford, 1993; Frost, 1988; Hargreaves et al., 2014); (ii) the largest yield decrease took place during the first cut (Frost, 1988; Hargreaves et al., 2014); (iii) yield may increase significantly for the second cut, however, the total yield for the year is not significantly more than for a zero traffic system (Elonen, 1986; Hargreaves et al., 2014). Douglas et al. (1995) conducted an eight-year experiment to investigate the effect of zero and reduced ground pressure traffic systems on forage yield in a comparison with a $\mathrm{N}$ system in Scotland (ryegrass and clay loam soil). Over the period 14.7\% (13.7 $\left.\mathrm{t} \mathrm{ha}^{-1}\right)$ and 14.0\% (13.1 $\left.\mathrm{t} \mathrm{ha}^{-1}\right)$ more dry matter was produced with zero traffic and reduced ground pressure systems respectively, than the $\mathrm{N}$ system, with the largest yield decrease generally in the first cut for $\mathrm{N}$ traffic (wet soil conditions related to the amount of rainfall following spring application of 
fertiliser), also, $\mathrm{N}$ traffic with wet soil conditions during cutting decreased the yield of the next cut.

Controlled Traffic Farming (CTF) is a traffic management system where all the field traffic is confined to permanent wheel ways across the field (Chamen, 2011). The trafficked area depends on the base module width: for example: 6-8 m systems result in approximately 25\% of the field having a trafficked area, reducing to approximately $17 \%$ for $12 \mathrm{~m}$ systems (Chamen, 2011). Although CTF systems are becoming accepted for cereal production in the UK, currently with some 50,000 ha in production (Godwin, 2015), there are no robust data about CTF for grassland. Kjeldal (2013) and Pedersen (2012) reported that CTF is practiced for grass production in Scandinavia, with the most popular module width of $12 \mathrm{~m}$ (trafficked area from 13 to $26 \%$ ) and mower widths from 6 to $12 \mathrm{~m}$.

In terms of the economics of CTF for grassland production Stewart et al. (1998) reported on an evaluation of perennial ryegrass grown for silage in contrasting wheel-traffic systems on clay loam soil in a Scottish climate. Based on eight years of experimental data the zero and reduced ground pressure traffic systems produced gross margins (GM) of $£ 500 \mathrm{ha}^{-1}$ and $£ 503$ ha $^{-1}$ respectively, $19 \%$ greater than the GM in the N system ( $\left.£ 421 \mathrm{ha}^{-1}\right)$. The estimated current value of these margins are $£ 714 \mathrm{ha}^{-1}, £ 718 \mathrm{ha}^{-1}$ and $£ 601 \mathrm{ha}^{-1}$, taking into account the Consumer Prices Index published by the UK Office for National Statistics. Alvemar (2014) conducted an economics study on the profitability of CTF for grass silage production based on dairy farms in Sweden. The economics models were developed and tested on a hypothetical dairy farm consisting of 300 ha of clay soils (144-160 ha in grassland), 300 dairy cows and single farm payments of $143 £ \mathrm{ha}^{-1}$ (exchange rate $1 \mathrm{GBP}=12.1$ SEK March 2016). This suggested that yield increase is the most important factor affecting the profitability when converting to CTF. The potential extra profit due to CTF was $£ 40$ to $£ 49 \mathrm{ha}^{-1} \mathrm{yr}^{-1}$.

The objectives of this work were to: (i) use a $9 \mathrm{~m}$ wide CTF system for one season to assess the potential increase in grass dry matter (DM) yield, (ii) review the commercially available equipment and (iii) use the values derived to determine the economic value of implementing a CTF system for grass production.

\section{Materials and methods}

Experimental site and baseline measurements

An 8 ha perennial ryegrass (Lolium perenne) field (freely drained sandy loam soil) at SRUC Dairy Research Farm, Southwest Scotland (N55:02:45, W03:35:56) was split into two 3.5 ha areas. Management history of the grass sward was the same up to the point the field was split in April 2015. The layout of each field was a rectangle (218 m x $160 \mathrm{~m}$ ) with one of two traffic management treatments imposed: $\mathrm{N}$ and CTF.

Forty initial measurement points were set up on a grid system across both the treatment fields before the first silage cut. Measurements of penetrometer resistance, soil bulk density (0-10 $\mathrm{cm}$ ) and soil visual evaluation of soil structure (VESS) were completed at each sampling point to confirm the uniformity of soil structure. Soil samples were also taken from each point to assess the variation of phosphorous $(\mathrm{P})$ and potassium $(\mathrm{K})$ levels along with the $\mathrm{pH}$, that could contribute to yield prior to management during the season.

\section{Field management}

The field was managed as a three cut silage system in May, July and August. Silage was harvested via a three $3 \mathrm{~m}$ beam mower (overall working width $9 \mathrm{~m}$ (See Figure 1a)). Following mowing, spreading and raking operations brought the three cut rows into one central row. The cut grass was harvested the following day with a forage harvester (width to outer edges of wheels, $3.1 \mathrm{~m}$ ) and two tractor and trailer combinations (tractor wheels outer width $3.2 \mathrm{~m}$ ). The latter ran alongside the harvester (approximately $2 \mathrm{~m}$ away) for the $\mathrm{N}$ and 
along the next set of parallel wheel tracks for the CTF system, thus maintaining a $9 \mathrm{~m}$ separation and providing a trafficked area of $19 \%$.

Dairy cow slurry at a rate of $30 \mathrm{~m}^{3} \mathrm{ha}^{-1}$, by tanker and splash plate, was applied twice through the season (May and July, after the silage cuts); the second application in July was applied with a narrower application band as a result of the thicker consistency of the slurry. The CTF management pattern had to follow one of the wheel tracks and added a further wheeling to the original pattern resulting overall in $30 \%$ of the area tracked. Inorganic fertiliser, as urea, was applied at a rate of $60 \mathrm{~kg} \mathrm{~N}$ ha after the first cut.

A GPS system with a $15 \mathrm{~cm}$ pass to pass accuracy and sight posts set up at the ends of each A-B line, for a manual check on the accuracy, allowed the same wheel tracks to be followed in the CTF system. The operations on the $\mathrm{N}$ field were conducted first to reduce any bias of machinery operators from the controlled movements. Each field was cut around the headlands three times and then the A-B lines completed using the headlands for turning. Real Time Kinematic (RTK) GPS tracked all vehicle movements across both treatment fields ( $\mathrm{N}$ and CTF) during grassland management. The RTK systems enabled operators to return to the same location in the field repeatedly to within $+/-25 \mathrm{~mm}$ for the CTF system. The intensity and spatial coverage of traffic across each treatment for each field operation were identified from the RTK traffic maps.

Total yield off-takes from both fields were recorded at each harvest by weighing each full trailer using a static weigh bridge. DM contents were calculated from 10 grab samples from each trailer after it had been weighed.

\section{Statistical analysis}

Data were analysed using Genstat version 16 (VSN International, Hemel Hempstead). The main treatments of tractor passes and $\mathrm{N}$ compared to CTF were analysed on a randomised basis using Genstat ANOVA. Any significance was investigated with a student t-test at a level of significance of $\mathrm{P}<0.05$.

\section{Results}

\section{Field experiment}

The baseline physical measurements taken at the initial 40 sampling points in the grid across the fields, showed no significant differences in soil structural condition. The chemical assessment of the soil at the same sampling points across the two fields did produce a significant difference $(\mathrm{P}<0.001)$ between the $\mathrm{N}$ and $\mathrm{CTF}$ for soil extractable phosphorous. However, the concentration of $\mathrm{P}$ would indicate that extra $\mathrm{P}$ was unlikely to provide any additional growth response to grass (PDA, 2011).

Table 1. Total Dry Matter (DM) off-take and differences (t/ha) from the two field systems, normal (N) and controlled traffic farming (CTF).

\begin{tabular}{llllll}
\hline Silage cut & \multicolumn{2}{l}{ Field system } & Difference & s.e.d. & \multirow{2}{*}{ P value } \\
\cline { 1 - 3 } & $\mathrm{N}$ & $\mathrm{CTF}$ & & & \\
\cline { 1 - 4 } $1^{\text {st }}$ silage cut & 5.28 & 5.43 & 0.15 & 0.019 & 0.27 \\
$2^{\text {nd }}$ silage cut & 3.58 & 3.88 & 0.30 & 0.007 & 0.72 \\
$3^{\text {rd }}$ silage cut & 2.34 & 2.84 & 0.50 & 0.001 & $\mathbf{0 . 0 1}$ \\
$2^{\text {nd }}+3^{\text {rd }}$ silage cut & 5.92 & 6.72 & 0.80 & & \\
Total silage & 11.29 & 12.15 & 0.96 & & \\
\hline
\end{tabular}


The weather during the management of the field (March to September) was wetter than the long-term average (1980 to 2010) for March (+38.8mm), May +42.5mm), July + 70.4mm) and Aug $(+20.5 \mathrm{~mm})$; the mean air temperature was very similar $\left(0.3^{\circ} \mathrm{C}\right.$ lower $)$ to the longterm mean $\left(11.7^{\circ} \mathrm{C}\right)$ during the same period. There was no significant difference in yield for the treatments during the first cut (Table 1 ). The 2nd silage cut gave a $0.30 \mathrm{t} / \mathrm{ha}$ increase in $\mathrm{DM}$ yield for the CTF compared to the $\mathrm{N}$ field $(\mathrm{P}=0.72)$ and $(0.5 \mathrm{t} / \mathrm{ha}(\mathrm{P}<0.01))$ for the 3rd silage cut compared to the $\mathrm{N}$.

\section{Discussion}

\section{Field experiment}

As expected the difference in DM yield was only $0.15 \mathrm{t} / \mathrm{ha}(\mathrm{P}=0.27)$ between the two fields for the first silage cut, as the systems had not been established prior to this cut and were the same across both fields. The differences in yield between the two fields increased as management operations continued for the $2^{\text {nd }}$ and $3^{\text {rd }}$ silage cuts. DM yield of the second and third cuts combined gave a $13.5 \%$ ( $0.80 \mathrm{t} / \mathrm{ha})$ increase for the field with the $9 \mathrm{~m}$ CTF system compared to the $\mathrm{N}$ field $(\mathrm{P}<0.05)$. This was very similar to the mean $\mathrm{UK}$ figure from the literature for the increase of CTF over $\mathrm{N}$ traffic from soil compaction of $13 \%$. The $9 \mathrm{~m}$ working width was chosen from a consideration of available equipment.

\section{Commercially available equipment}

A wide range of commercial equipment was assessed to determine their basis for different widths of CTF system within grass silage production. The aim for each system was to select a combination of machinery that could be used with little or no physical modification or impact on field operations. Additionally, the machines were assessed for compatibility with potential arable (combinable crop) operations on the same farm.

CTF systems ranging from common widths of $3 \mathrm{~m}$ to $12 \mathrm{~m}$ were feasible, with tracked areas ranging from $40 \%$ to $13 \%$. When arable operations were introduced, the tracked areas ranged from $58 \%$ to $18 \%$. Several options were possible, with the 5, 9 and $12 \mathrm{~m}$ systems leading to the lowest tracked areas for both grassland and arable operations (Table 2).

\section{Table 2. Summary of the different CTF systems proposed and their associated tracked} areas.

\begin{tabular}{|c|c|c|c|c|}
\hline \multicolumn{2}{|c|}{ Controlled traffic base widths } & \multirow[b]{2}{*}{ Forage system } & \multicolumn{2}{|c|}{ Trafficked area, \% } \\
\hline Mowing width (m) & Other widths (m) & & Grass only & Grass \& arable \\
\hline \multirow{4}{*}{1.5 or 3.0} & $6.0 \& 9.0$ & Loader wagon & 35.9 & 48.4 \\
\hline & & & & 57.8 (6 m combine) \\
\hline & & & & 49.7 (9 m combine) \\
\hline & & Trailed forager & 34.3 & 57.8 (6 m combine) \\
\hline \multirow[t]{3}{*}{3.0} & $6.0 \& 9.0$ & Self-propelled & 40.1 & 44.1 \\
\hline & & & & 64.4 (6 m combine) \\
\hline & & & & 44.1 (9 m combine) \\
\hline \multirow[t]{3}{*}{4.0} & 8.0 & Loader wagon & 27.7 & 35.7 (4 m combine) \\
\hline & & & & 40.5 (8 m combine) \\
\hline & & & & 37.0 (8 m combine $)^{1}$ \\
\hline 5.0 & & Loader wagon & 21.5 & 31.1 \\
\hline 9.0 & & Self-propelled & 18.2 & 22.0 \\
\hline 12.0 & & Self-propelled & 13.4 & 18.2 \\
\hline
\end{tabular}

Formatted: Superscript

Formatted: Superscript 
There are two shortcomings with the 4 and $5 \mathrm{~m}$ systems: a) loader wagon is required and are relatively uncommon in the $\mathrm{UK}$, and b) the mower has heavily loaded wheels running on the non-trafficked bed. A 3 m system involves machines with little or no modification but requires a tractor with a track gauge of $1.5 \mathrm{~m}$ and because of its narrower width, has a greater tracked area than the wider systems.

A 9 m system is achievable based on mowers such as in Figure 1a, along with standard tedders, swathers, harvester and dribble bar slurry applicator (Figure 1b). Harvesting with this $9 \mathrm{~m}$ system relies on delivery from a self-propelled harvester to a rear hitch trailer that is swopped on the headland when full. There is presently no option for delivering to a trailer running in the adjacent traffic lane $9 \mathrm{~m}$ away. A further reduction in tracked area could be achieved if the gauge of the harvester and other machinery in the operation were more closely aligned (Table 3). Introducing arable operations to this system does not increase the tracked area overly, with a predicted $22 \%$ being achieved (Table 3 ).

The greatest constraint when introducing a $9 \mathrm{~m}$ or any other CTF system is its effect on harvesting work rate. Where a tractor and trailer are involved for example, the present action is for the driver to take the shortest route to the field exit, but this would compromise the system completely. Extra discipline and commitment are central to the success of any CTF system used for grass forage production. In addition there would be a curtailment of harvest work rates associated with forage trailers running along traffic lanes rather than taking the shortest route to the harvester or field exit.
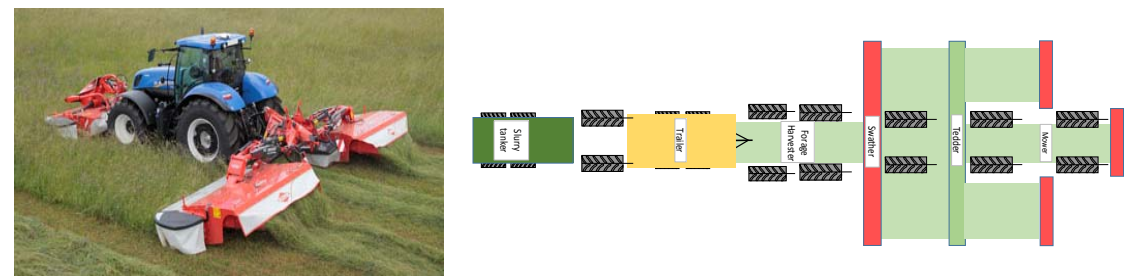

a)

b)

Figure 1 a) Triple gang mower of the type envisaged for a $9 \mathrm{~m}$ controlled traffic system and $b$ ) illustration of the machines and operations involved

Table 3 Machinery assumed for a $9 \mathrm{~m}$ controlled traffic system

\begin{tabular}{|c|c|c|c|c|}
\hline Machine & $\begin{array}{l}\text { Working } \\
\text { width }(\mathrm{m})\end{array}$ & $\begin{array}{l}\text { Operating } \\
\text { width (m) }\end{array}$ & $\begin{array}{l}\text { Tyres on } \\
\text { principal axle }^{1}\end{array}$ & $\begin{array}{l}\text { Track } \\
\text { gauge }(\mathrm{m})\end{array}$ \\
\hline Claas Axion tractor & $\mathrm{n} / \mathrm{a}$ & $\mathrm{n} / \mathrm{a}$ & $710 / 70$ R 38 & 2.0 \\
\hline Kuhn GMD 9530 triple gang mower & $9.13-9.53$ & 9.0 & & \\
\hline Claas Volto tedder & 10.7 & 9.0 & & \\
\hline Kuhn GA 9531 swather & $8.4-9.30$ & 9.0 & & \\
\hline Claas Jaguar 980/940 harvester & & 9.0 & 710/70 R 42 & 2.20 \\
\hline Richard Western silage trailer & $\mathrm{n} / \mathrm{a}$ & 9.0 & $15 \times 22.5-18 \mathrm{PR}$ & 2.0 \\
\hline Conor slurry tanker + trailing shoe & 9 & 9.0 & 560/60 R 22.5 & 2.04 \\
\hline $\begin{array}{l}\text { Agrisem Vibromulch stubble } \\
\text { cultivator }\end{array}$ & 9 & 9.0 & & \\
\hline Dale Eco-Drill & 9 & 9.0 & & \\
\hline John Deere 9000 series combine & 9.14 & 9.0 & 650/75 R 32 & 2.61 \\
\hline Grain chaser & 2.91 & 9.0 & $800 / 40$ R 26.5 & 2.11 \\
\hline
\end{tabular}

${ }^{1}$ Tyres on the axle that creates the widest footprint for the particular machine. 


\section{Economics analysis}

The economics analysis followed a similar format to Godwin et al. (2003) for assessing the potential for precision farming in cereal production. It considered the direct economic advantages from any improvements in forage yield alongside the additional costs of implementation, but did not include other less tangible benefits such as the savings in reestablishment and fuel costs.

A range of trafficked areas (\%) were used in the calculations, as the trafficked area depends upon the operating track gauges and wheel widths of available equipment, this should enable farmers and/or contactors to estimate the benefits of CTF for their system, as well as an individual farmer and/or contractor to estimate future benefits with the longer-term investment in replacement equipment. As the cost/ha is influenced by the area harvested/cut the analysis was conducted for a range of areas up to 1500ha/cut based upon harvesting rates of 75ha/day (Farmers Weekly, 2016 and Cottey, 2016) and 20 work-days/cutting period. The annual benefits of CTF were based upon the following assumptions: (i) average yield for 2 and 3 "cut" managed grassland harvest systems in the UK is $12 \mathrm{tha}^{-1}$ and $16.6 \mathrm{t} \mathrm{ha}^{-1}$ of dry matter respectively, with a value of $£ 72 \mathrm{t}^{-1}$ (SRUC, 2016), (ii) conventional traffic management covers $80 \%$ of the field area and (iii) the removal of the traffic increases forage yields by $13 \%$.

The additional annual cost of CTF over random traffic farming was based upon four different levels of capital investment (Table 4), as the level of expenditure is dependent upon the scale of the operation. The additional costs are focused on the costs of the guidance systems only, as it is assumed that initially a farmer or contractor would use existing equipment (as discussed earlier) and that improvements to equipment matching would be part of the normal longer-term replacement policy. In practice, multiple field vehicles would need to be fitted with guidance systems and therefore in the analysis, the costs of each individual system were estimated, from which the costs of up to 4 systems guidance systems are considered.

Table 4. Current typical commercial equipment guidance costs/system (less VAT).

\begin{tabular}{|c|c|c|c|c|c|}
\hline Investment & Equipment & $\begin{array}{l}\text { Repeatable } \\
\text { positioning }\end{array}$ & $\begin{array}{c}\text { Capital } \\
\text { Cost }\end{array}$ & $\begin{array}{c}\text { RTK Annual } \\
\text { Fee }\end{array}$ & $\begin{array}{c}\text { Total Annual } \\
\text { Cost }^{\dagger}\end{array}$ \\
\hline Level 1 & $\begin{array}{l}\text { Low accuracy* } \\
\text { Manual steering }\end{array}$ & No & $£ 1,500$ & - & $£ 467.5$ \\
\hline Level 2 & $\begin{array}{l}\text { Low accuracy* } \\
\text { Assisted steering }\end{array}$ & No & $£ 5,000$ & - & $£ 1325$ \\
\hline Level 3 & $\begin{array}{l}\text { High accuracy** } \\
\text { Assisted Steering }\end{array}$ & Yes & $£ 10,000$ & $£ 500$ & $£ 3050$ \\
\hline Level 4 & $\begin{array}{l}\text { High accuracy** } \\
\text { Integrated steering }\end{array}$ & Yes & $£ 15,000$ & $£ 500$ & $£ 4275$ \\
\hline $\begin{array}{l}*(+/-150-200 \mathrm{r} \\
\text { positioning. } \\
* *(+/-20 \mathrm{~mm}) \mathrm{R} \\
{ }^{+} \text {The total ann } \\
(£ 100 / \text { year })(\mathrm{N} \\
\text { Analysis sho } \\
0.53 \mathrm{t} \mathrm{ha}^{-1} \text { an } \\
\text { area was red } \\
\text { for the } 2 \text { and } \\
\text { and } £ 98 \text { ha }^{-1} \\
\text { when adjuste }\end{array}$ & $\begin{array}{l}\text { n), These will result in a } \\
\text { Time Kinematic (RTK } \\
\text { cost includes interest } \\
2015 \text { ). } \\
\text { ed that reducing the } \\
0.73 \mathrm{t} \mathrm{ha}^{-1} \text { for the } 2 \\
\text { ed to } 15 \% \text { this furth } \\
\text { cut systems, respect } \\
\text { d agreed with sugge } \\
\text { for retail price inflat }\end{array}$ & $\begin{array}{l}\text { ates (4.5\%), d } \\
\text { fficked area } \\
\text { d } 3 \text { cut syste } \\
\text { increased th } \\
\text { ely. These yi } \\
\text { ed benefits } \\
\text { n; Alvemar, }\end{array}$ & $\begin{array}{l}\text { eciation }(1 \\
\text { m } 80 \% \text { tc } \\
\text { respectiv } \\
\text { ield benef } \\
\text { increases } \\
\text { earlier s }\end{array}$ & $\begin{array}{l}\text { ), maintenance } \\
5 \% \text { increased } \\
\text { v. However, if } \\
\text { to } 1.00 \mathrm{t} \mathrm{ha}^{-1} \mathrm{a} \\
\text { vere valued be } \\
\text { dies (Stewart }\end{array}$ & $\begin{array}{l}\text { id non-repeatable } \\
\%) \text { and training } \\
\text { le yield by } \\
\text { le trafficked } \\
\text { d } 1.36 \mathrm{t} \mathrm{ha}^{-1} \\
\text { veen } £ 38 \mathrm{ha}^{-1} \\
\text { al. (1998) } \\
\text { rafficked area }\end{array}$ \\
\hline
\end{tabular}


systems respectively. The cost/ha/year for 4 low accuracy - manual steering systems is less than $£ 18.70$ for areas in excess of 100 ha/harvest; 4 high accuracy (RTK) - integrated systems cost less than $£ 85.50$ for areas in excess of 200 ha/harvest reducing to $£ 11.40$ for areas greater than 1500 ha/harvest. The break-even area for 4 low accuracy - manually steered systems is 50 ha/year for a $45 \%$ trafficked area CTF system with 2 cuts /year and increases to 450 ha/year for 4 high accuracy (RTK) - integrated steering systems. With 3 cuts a year the breakeven area for four low accuracy - manually steered systems is 28 ha/year for a $35 \%$ trafficked area. This increased to 78 ha/year for 4 low accuracy - assisted steering systems and 250 ha for 4 high accuracy (RTK) - integrated steering systems. With a CTF system having a trafficked area of 15\% the break-even area for 4 high accuracy (RTK) - integrated sterring systems is 175 ha. The data given in Hargreaves et al. (2016) are aimed at allowing the benefits, costs and break-even areas of individual systems to be estimated and investment choices to be made.

\section{Conclusion}

The combined yield of the second and third cuts gave a $13.5 \%$ (0.80 t/ha) increase for the CTF field compared to the $\mathrm{N}$ field indicating a relatively rapid response to CTF as a result of the reduced soil structural damage--

There are suitable ranges of commercially available equipment to enable farmer/contractors to design CTF systems with module widths from $3 \mathrm{~m}$ to $12 \mathrm{~m}$.

Overall the economics analysis showed that provided navigation systems are wisely selected for the size of the operation and their constraints recognised, then CTF in grass silage production can be cost effective. There were reductions in the cost of production with both 2 and 3 cut silage systems. The data also provides a basis for negotiation between a farmer and contractor when considering the benefits and costs of grass CTF systems.

\section{Acknowledgements}

This work was funded by AHDB Dairy as part of the Grassland, Forage and Soils partnership.

\section{References}

Alakukku, L (1999). Subsoil compaction due to wheel traffic. Agricultural and Food Science in Finland, 8, 333-351.

Alvemar, H (2014).Controlled traffic for grass silage production - An economic evaluation for dairy farmers. Degree thesis No 889. Swedish University of Agricultural Sciences, Uppsala.

Are, M, Reintam, E, Selge, A, Sanchez de Cima, D (2015). Mulla tallamise järelmõju mulla omadustele ja rohumaa saagikusele (The after-effect of soil compaction on soil properties and grassland productivity). Ed. Alaru, M; Astover, A; Karp, K; Viiralt, R; Must, A Agronoomia 2015 (10-15). Tartu: Ecoprint.

Chamen, WTC (2011). The effects of low and controlled traffic systems on soil physical properties, yields and the profitability of cereal crops on a range of soil types. Unpublished $\mathrm{PhD}$ thesis, Cranfield University.

Chyba, J, Kroulík, M, Krištof, K, Misiewicz, PA, Chaney, K (2014). Influence of soil compaction by farm machinery and livestock on water infiltration rate on grassland.

Agronomy Research, 12, 59-64.

Cottey, D (2016). Personal communication, Claas UK, Saxham.

Farmers Weekly. 25 $5^{\text {th }}$ March 2016 and $1^{\text {st }}$ April 2016. Reports on Forage Harvesting Equipment. 
Davies, B, Eagle, D, Finney, B (1993). Soil Management. 5th Ed. Farming Press, Ipswich 280p.

Douglas, JT and Crawford, CE (1991). Wheel-induced soil compaction effects on ryegrass production and nitrogen uptake. Grass and Forage Science, 46, 405-416.

Douglas, JT, Campbell, DJ, Crawford, CE (1992). Soil and crop responses to conventional, reduced ground pressure and zero traffic systems for grass silage production. Soil \& Tillage Research, 24, 421-439.

Douglas, JT and Crawford, CE (1993). The response of a ryegrass sward to wheel traffic and applied nitrogen. Grass and Forage Science, 48, 91-100.

Douglas, JT, Crawford, CE, and Campbell, DJ (1995). Traffic Systems and Soil Aerator Effects on Grassland for Silage Production. Journal of Agricultural Engineering Research, 60, 261-270.

Elonen, P (1986). Jordpackning - ett problem i Finsk åkerodling. Rapporter från jordbearbetnings avdelningen (Soil compaction - a problem in Finnish arable farming). Ed. I. Håkansson, J von Polgár \& K Rask. Reports from the Division of Soil Management, No. 71. Swedish University of Agricultural Sciences, Uppsala.

Frost, JP (1988). Effects on Crop Yields of Machinery Traffic and Soil Loosening. Part 1.

Effects on Grass Yield of Traffic Frequency and Date of Loosening. Journal of Agricultural Engineering Research, 39, 301-312.

Godwin, RJ, Richards, T E, Wood, GA, Welsh, JP, Knight, S (2003). An economic analysis of the potential for precision farming in UK cereal production. Biosystems Engineering, 84, 533-545.

Godwin, RJ (2015). Precision Farming. Ingenia, 64, Royal Academy of Engineering, London Hargreaves, P, Ball, B, Baker, K (2014). DairyCo Soil Compaction Progress Report: Grass Yield and Soil. SRUC Research \& Harper Adams University.

Hargreaves, P, Peets, S, Chamen WCT, Misiewicz, PA, White, DR, Godwin, RJ (2016).

Controlled Traffic Farming: Methods applied to Grassland Silage Management, AHDB Dairy Report. In press. Stoneleigh Park, Kenilworth, Warwickshire, CV8 2TL.

Kjeldal, M (2013). Contractors improve yield and feed quality by use of CTF in forage grass. First International CTF Conference, Toowoomba, Australia.

Kroulík, M, Misiewicz, P, Chyba, J, White, D (2014). Field traffic intensity for forage harvesting in the UK. Harper Adams University Project Report 099.

Nix, J (2015). Farm Management Pocketbook. 46 ${ }^{\text {th }}$ (2016) Edition. Agro Business

Consultants Ltd.

PDA (2011). Soil Analysis Key to Nutrient Management Planning - PDA Leaflet 24. Potash Development Association, York, UK.

Pedersen, HH (2012). Mosegaarden, 12 m CTF forage grass. CTF Europe.

http://ctfeurope.com/2012/grass/ [Retrieved 24/04/2015].

Raghavan, GSV, McKyes, E, Stemshorn, E, Gray, A, Beaulieu, B (1977). Vehicle compaction patterns in clay soil. Transactions ASAE, 20, 218-220.

Rasmussen, KJ and Møller, E (1981). Genvækst efter fortørring af græsmarksafgrøder. II. Jordpakning i forbindelse med høst og transport (Regrowth after pre-wilting of grassland crops. II. Soil compaction in connection with harvest and transport). Tidskr. Planteavl. 85, 59-71. As cited in: Alvemar, H (2014). Controlled traffic for grass silage production - An economic evaluation for dairy farmers. Degree thesis No 889. Swedish University of Agricultural Sciences, Uppsala.

Reintam, E, Krebstein, K, Sanchez de Cima, D, Leeduks, J (2013). Mulla tallamise mõju karjamaa raiheina ja hübriidlutserni saagikusele (Impact of soil compaction on productivity of rye grass and lucerne). Ed. T. Kangor; S. Tamm; R. Lindepuu Agronoomia 2013 (22-27). SRUC. (2016). Personal communication. 
Stewart, L, Copland, T, Dickson, J, Douglas, J (1998). Economic evaluation of traffic systems for arable and grass crops on an imperfectly drained soil in Scotland. Journal of Sustainable Agriculture, 12, 41-56. 